\author{
FASCICULI ARCHAEOLOGIAE HISTORICAE \\ FASC. XXXI, PL ISSN 0860-0007 \\ DOI 10.23858/FAH31.2018.013
}

ANNA RYBARCZYK*

\title{
TEXTILES AND SOCIAL STATUS. THE CASE OF LATE MEDIEVAL ELBLĄG
}

\begin{abstract}
High quality textiles were unquestionably one of the most luxurious goods in the Middle Ages. Expensive fabrics, especially silks are recognised as indicators of the owner's high social status. The excavations conducted in Elbląg (Elbing) gave rise to a very interesting collection of textiles. The fact that most of these finds came from parcels with well-known historical background offers a rare opportunity to relate the discovered textiles to their owners. It is also possible to link certain types of fabrics mentioned in written sources to actual archaeological finds. Combining archaeological and historical data enables us to shed some light on the question of using expensive textiles by townspeople in a late medieval Hanseatic town. A great correspondence of these sources as far as textile evidence is concerned can be observed: types of textiles listed in the sumptuary laws were successfully identified in the excavated evidence.
\end{abstract}

Keywords: Elbląg (Elbing), Middle Ages, silk, social status, written sources

High quality textiles were unquestionably one of the most luxurious goods in the Middle Ages. ${ }^{1}$ Therefore, expensive fabrics, especially silks and imported broadcloths, are recognised as indicators of the owner's high social status. Combining archaeological and historical data enables us to shed some light on the question of using expensive textiles by townspeople in a late medieval Hanseatic town. The aim of the present paper is to make such an attempt based on archeological evidence and written sources from Elbląg (Elbing). The excavations conducted in Elbląg gave rise to a very interesting collection of textiles. The fact that most of these finds came from parcels with well-known historical background offers a rare opportunity to relate the discovered textiles to their owners. It is also possible to link certain types of fabrics mentioned in written sources to actual archaeological finds.

Gold and precious jewellery are commonly thought to have been visual signs of wealth in the past centuries; however, in the Middle Ages, they were only one of the elements that signified one's high social status. Among goods that could be considered luxurious, high quality textiles and

\footnotetext{
* Institute of Archaeology and Ethnology, Polish Academy of Sciences; (D) https://orcid.org/0000-0003-2210-1585; annamaria. rybarczyk@wp.pl

${ }^{1}$ This paper is part of the author's $\mathrm{PhD}$ dissertation Odziez $i$ akcesoria stroju w średniowiecznym Elblagu, defended in 2016 at the Institute of Archaeology and Ethnology, Polish Academy of Sciences.
}

textile products would be the first on the list: colourful English and Flemish broadcloths, patterned silk textiles and glittering metal threads. As much as excavations carried out in Elbląg did not bring finds of precious jewellery, they provided a bulk of textile discoveries that contains remains of all aforementioned artefacts. Archaeological finds and written sources confirm the presence of imported broadcloth of high quality in Elbląg, best exemplified by the woollen textile in satin weave of the second half of the $13^{\text {th }}$ century. ${ }^{2}$ Other excavated silk textiles and narrow weaves prove that these products were available to the townspeople of Elbląg, and not only in a limited, modest assortment: practically, a full range of silk products of the period was employed.

The fact that medieval townspeople, if only capable of affording it, did not spare their money on clothing, is suggested by sumptuary laws repeatedly re-issued across Europe. These were supposed to guarantee proper modesty and observance of the dress code reflecting differences in people's social status. The situation in Elbląg was not any different. In Acten der Ständetage Preussens unter der Herrschaft des Deutschen Ordens, which also include a collection of laws issued for the towns in the Teutonic Order's State, an interesting bill of $1445^{3}$ can be found. It was an attempt at producing a formal regulation of the issue of manifestation of one's wealth through clothing and at tempering the townspeople's taste for luxury. Among the most

\footnotetext{
${ }^{2}$ Maik 1997, 15-16.

${ }^{3}$ Acten der Ständetage ..., 670-671.
} 

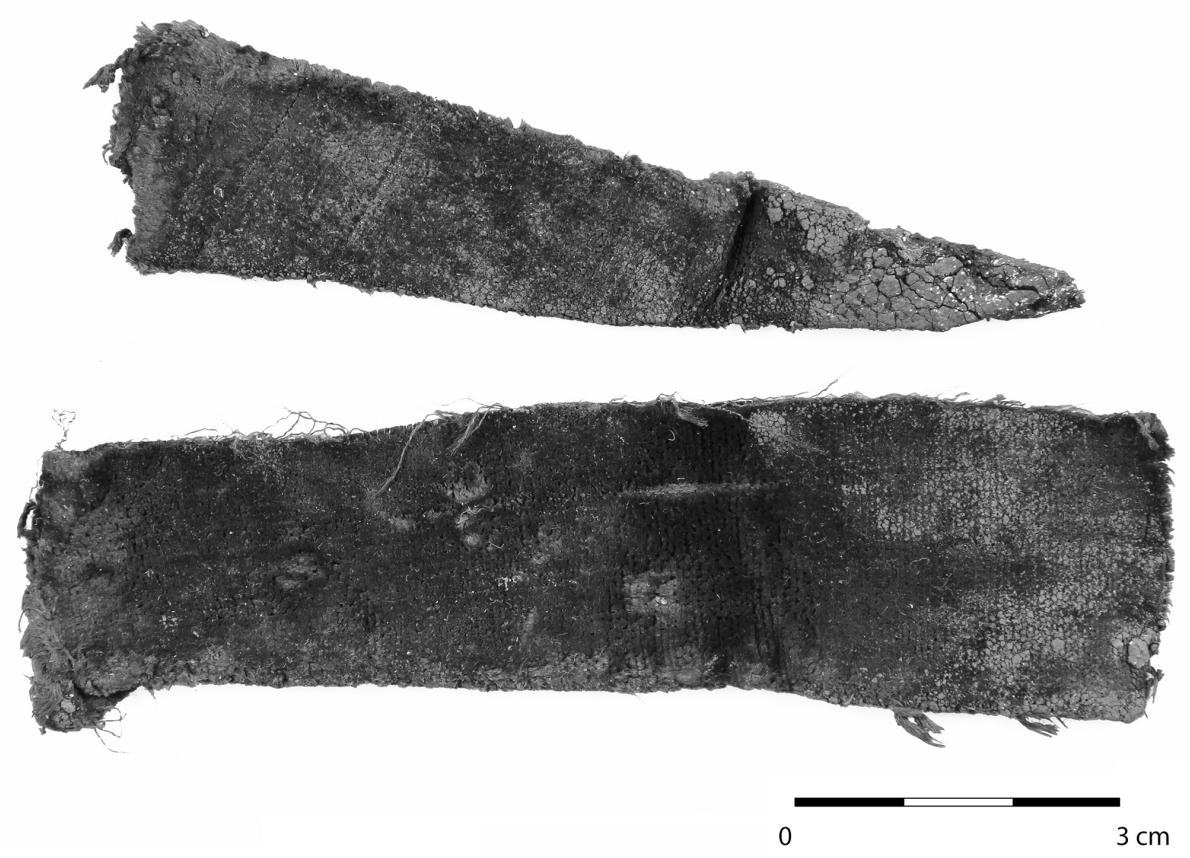

Fig. 1. Silk velvet (museum No. EM XXIII/38/2078). Photo A. Rybarczyk.

expensive elements of attire that were considered the privilege of the few, silk fabrics used for cloak trimmings are listed. Velvet - samt - was mentioned as the first. The term may stir doubts as to whether it refers to the fabric with a pile or to weft-faced compound twill known as samitum, yet these objections fade when the issue date of the bill is taken into consideration. In the $1440 \mathrm{~s}$, it was velvet that was the leading product of luxurious silk production, while weft-faced compound twill most likely was not woven in this time anymore. Wearing cloaks with a velvet decoration being worth not more than one and half marks was only allowed to dignified women (which most likely referred to spouses of town councillors or merchants, for instance), while it was forbidden to spouses of craftsmen. Among textile artefacts found in Elblacg, only one fragment of velvet ${ }^{4}$ (museum No. EM XXIII/38/2078) undisputedly dated to the medieval period was found (Fig. 1).

Beside velvet, the discussed bill lists two other kinds of silk textiles, also used to decorate cloak edges: balldige and kemmechen. In my opinion, these textiles should be identified with products known from Italian sources (Luca regulations of 1376 with revisions of 1381 and $1382^{5}$ ) as baldachini and camucha. They were variants of very decorative patterned silk textiles of complex weave known as lampas. Lampas named camucha was lampas textile with tabby ground and tabby pattern, while baldachini was lampas with tabby pattern and twill ground. ${ }^{6}$ It should be mentioned that textiles being counterparts of the Italian baldachini were identified

\footnotetext{
${ }^{4}$ Maik 2004, 512-514, Fig. 12.

${ }^{5}$ Mancini et al. 1927.

${ }^{6}$ King and King 1988, 70.
}

in archaeological evidence from Elbląg. ${ }^{7}$ Interestingly, one of these textiles (museum No. EM XXXI/3726) has the form of a long, rather wide strip that could have been placed along the coat's edge in the manner described in the bill. However, a certain gap in this theory on the original use of the artefact is the dating of the textile - while it was excavated from the layer generally determined as related to the $15^{\text {th }}$ century, the decorative ornament indicates an earlier date of its production which should rather not be linked to the fashion of the 1440s. On the other hand, such an expensive textile could have been in use for a long period of time.

Another decorative element whose use was intended to be limited by the authorities of the Teutonic Order were embroideries with gold threads. Unfortunately, no traces of embroidery have been discovered in Elbląg, yet remains of various bands produced with the use of metal threads were found. As known from European iconographic analogies, these were used to hem cuffs or collars. Although decorative silk ribbons are well known from archaeological sources (e.g. from the crypt of Kwidzyn Cathedral) ${ }^{8}$, a band of gold threads displaying a pattern most similar to the one on one of the galloons from Elbląg (Fig. 2) ${ }^{9}$ (museum No. EM XXII/2679) can be observed in the famous Arnolfini Portrait by Jan van Eyck, ${ }^{10}$ in the bride's cuff. The painting also shows one more use for wide galloons: they were namely used as women's wide belt.

\footnotetext{
${ }^{7}$ Rybarczyk 2016, 43-46.

${ }^{8}$ Grupa 2009, 154, 172-173.

${ }^{9}$ Maik 2004, 512, Fig. 9.

${ }^{10}$ The work is exhibited in the National Gallery in London: http://www.nationalgallery.org.uk/paintings/jan-van-eyck-thearnolfini-portrait (accessed 3.04.2018).
} 

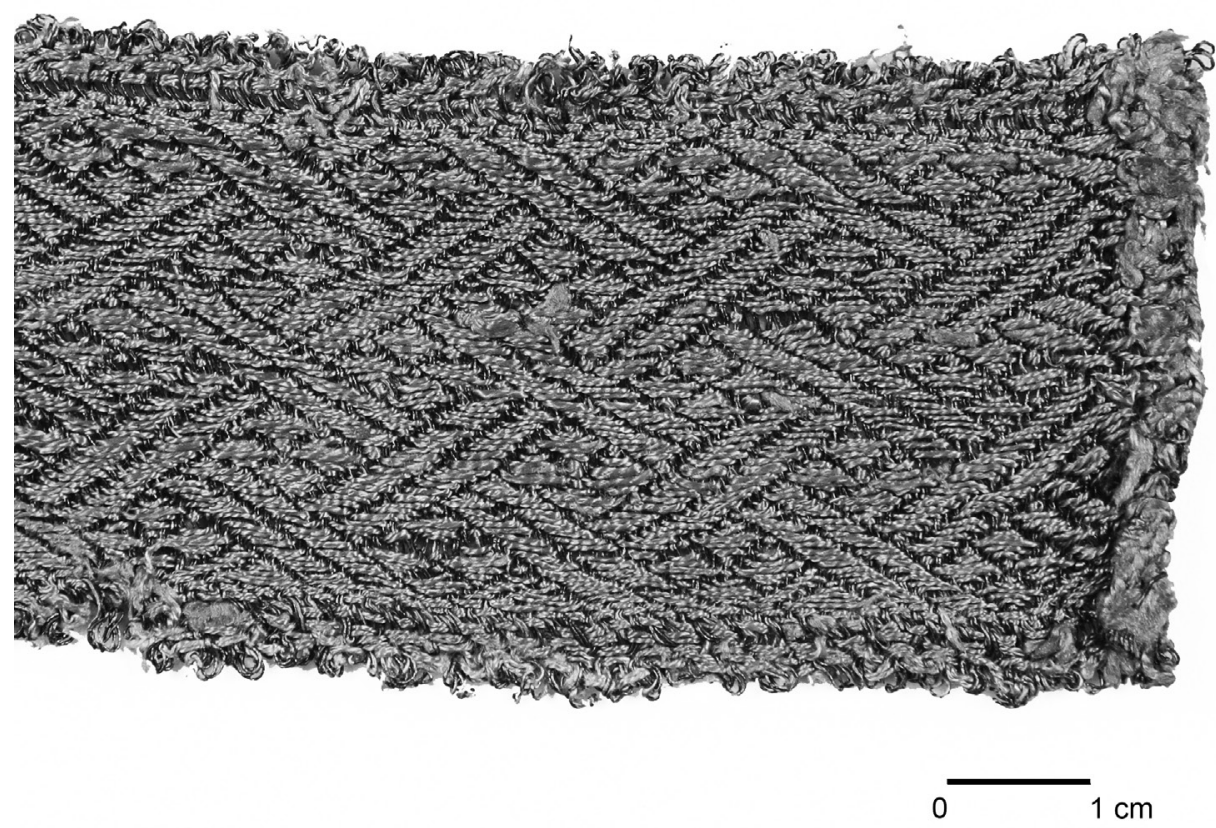

Fig. 2. Fragment of galloon (museum No. EM XXII/2679). Photo A. Rybarczyk.

A preserved example of such a girdle is the Italian sample of the mid- $15^{\text {th }}$ century in the collection of the Victoria and Albert Museum in London. ${ }^{11}$

While discussing the textiles listed in the Teutonic sumptuary law, it should be emphasised that it prohibits wearing of this type of textiles to persons of lower social position, like craftsmen, or, more precisely, their wives. It may suggest that these people could actually afford to buy these costly textiles and most likely did so. In this context, it would be interesting to compare the location of the discovery of the artefacts with available data on the material status and profession of the owners of particular parcels. It is possible on the basis of an analysis of extant written sources conducted by Roman Czaja. This historian is the author of a book dedicated to the sociotopography of medieval Elbląg. ${ }^{12}$ Another very important work, which may help shed some light on the discussed issue is an unpublished study describing the successive owners of town parcels since around 1400, prepared under the leadership of Antoni Czacharowski. ${ }^{13}$ This useful work was created as a compilation of various pieces of information from published medieval sources as well as from unpublished documents stored in the State Archive in Gdańsk.

The excavated imported silk and woollen textiles were marked on a sociotopographic map of the town by Jerzy Maik in his book Sukiennictwo elbląkie $w$ średniowieczu $u^{14}$, yet the discovery of new silk artefacts and changes in the dating of some of previous finds incline us to make an update.

\footnotetext{
${ }^{11}$ Campbell 2009, 7, Fig. 72.

${ }^{12}$ Czaja 1992.

${ }^{13}$ Czacharowski, Kartoteka ...

${ }^{14}$ Maik 1997, Fig. 57.
}

First of all, attention should be paid to the artefacts found in the $15^{\text {th }}$-century layers, since it is for this period that we have detailed data concerning the inhabitants of particular parcels. Among silk textiles and passementerie, the criterion is met by 15 items in total. It is worth examining in detail the location of selected examples of the most advanced silk textile and narrow weaves production (Fig. 3).

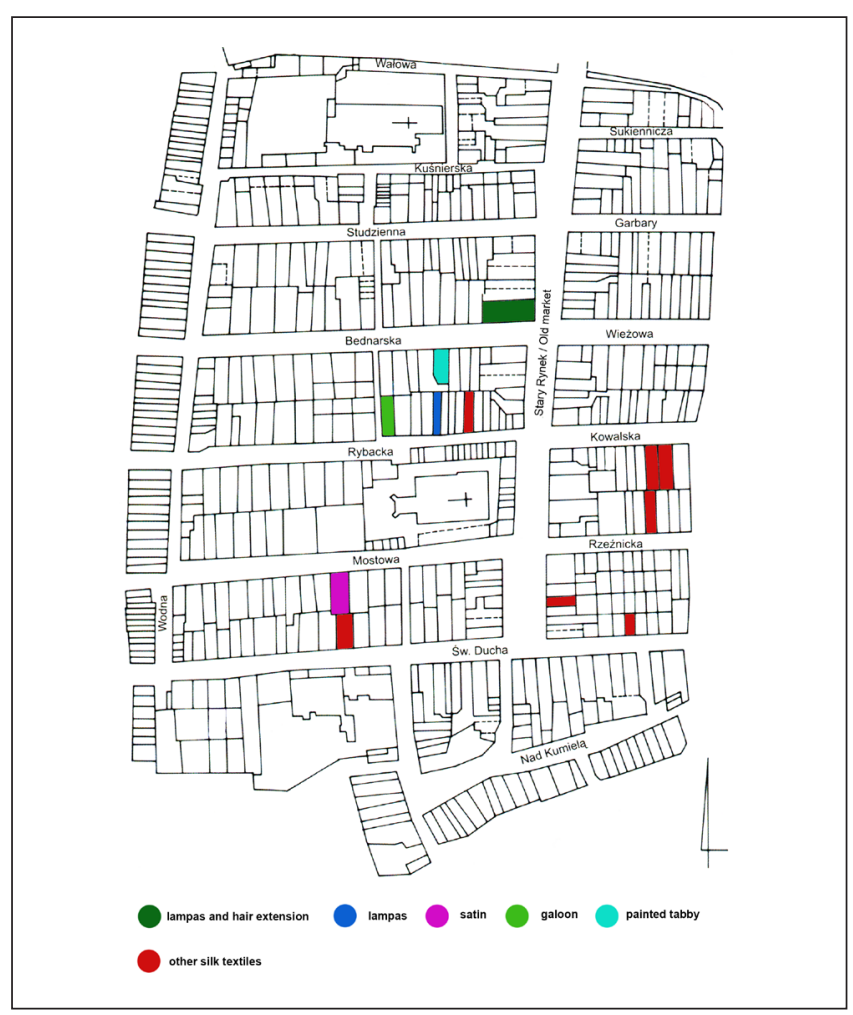

Fig. 3. Map of Elbląg with marked plots where $15^{\text {th }}$ century silk textiles were found. Drawing B. Kiliński (map) and A. Rybarczyk. 


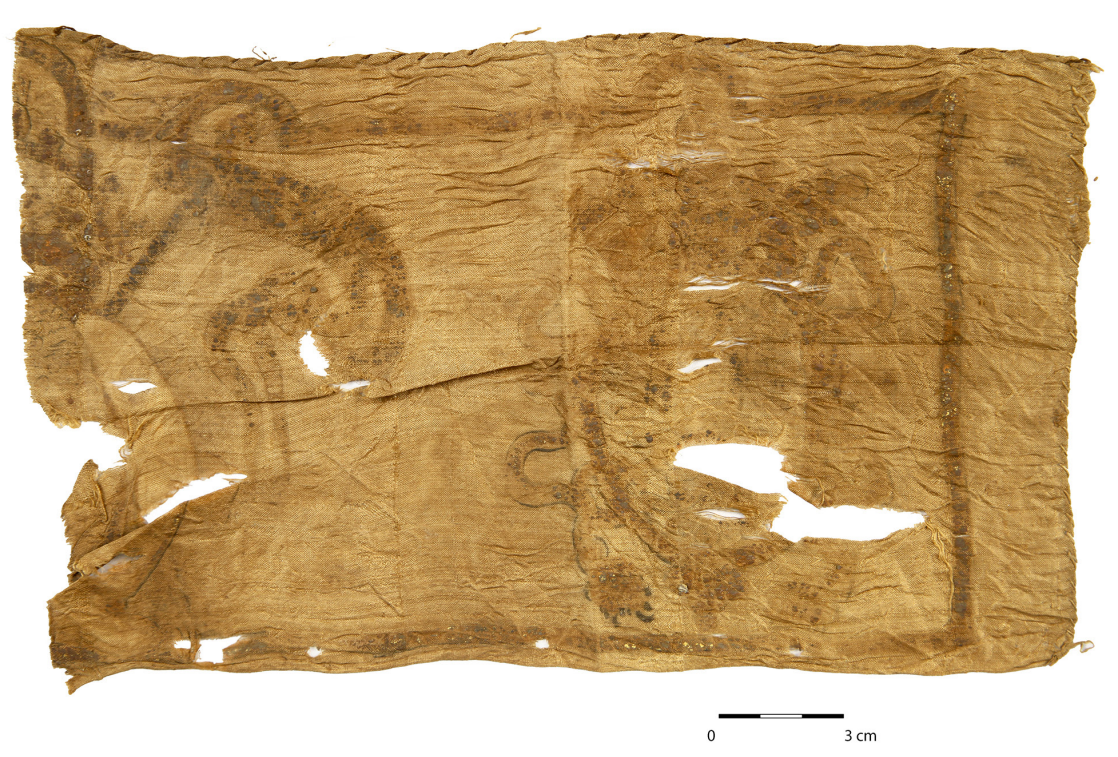

Fig. 4. Painted tabby (museum No. EM XXII/12.810). Photo A. Rybarczyk.

The long fragment of the lampas silk textile with the greyhound pattern ${ }^{15}$ (museum No. EM XXXI/3726) was excavated at Parcel 14 in the Old Market (in its part also known as the Coal Market); in the same place, a hair extension based on the core of expensive silk textiles (lampas and satin) was found (museum No. EM XXXI/3768).$^{16}$ It is known that in the first half of the $15^{\text {th }}$ century this place was inhabited by exceptionally wealthy people. ${ }^{17}$ In the years $1417-1421$, the house was inhabited by Lyffowodt van Herverden, a town councillor, alderman and municipal treasurer, representative of one of the wealthiest families from Elbląg, whose place of origin was Westphalia. Later on, the parcel was taken over by Jan Somewaldt, of whom we know nothing more. In 1457 , the house at this address was appointed the official lodging for Polish monarchs, which suggests its importance. ${ }^{18}$ The discovery of textiles and fashionable accessories of the highest quality exactly in this place is obviously not surprising.

Yet another distinguishing item - a lampas silk purse with the depiction of birds ${ }^{19}$ (museum No. EM XXII/3613) - was excavated at Building 28 in Rybacka Street that was inhabited in the $15^{\text {th }}$ century by rich merchants. ${ }^{20}$

The case of silk satin ${ }^{21}$ (museum No. EM XXIV/21.820) is similar. The parcel at Mostowa Street 14, where the artefact was found, was occupied in the first half of the $15^{\text {th }}$ century by people of high social position. In 1421, the house was inhabited by Heinrich Nourgarten, considered moderately

\footnotetext{
${ }^{15}$ Rybarczyk 2016, 43-45.

${ }^{16}$ Drążkowska 2012, 87, Fig. 61; Rybarczyk 2016, 68-69.

${ }^{17}$ Czaja 1992, Table 2, 7.

${ }^{18}$ Czacharowski, Kartoteka...

${ }^{19}$ Rybarczyk 2016, 45-46, 175-177.

${ }^{20}$ Czaja 1992, Table 2; 5; 7.

${ }^{21}$ Maik 2004, 511.
}

rich, the son of a town councillor and alderman; in the years 1426-1435, the house's owner was Liorencz Straube, possibly a merchant, while in the late $15^{\text {th }}$ century, the parcel was taken over by a town councillor Jorg Engelke. ${ }^{22}$

The history of the plot where the aforementioned sumptuous patterned galloon was found could also be traced. In 1420, in the house at Rybacka Street 36, a rather poor Heinrich Barbierer lived, and in successive years - a moderately rich Mattyas Kystenbuch. ${ }^{23}$

In a tenement house at Bednarska Street 14, where a silk tabby painted in gold (Fig. 4) ${ }^{24}$ (museum No. EM XXII/12.810) was discovered, a wealthy merchant named Claus Boryn lived in the years 1417-1435. He was the secular administrator of the Church of St George..$^{25}$

As evident, remains of the most precious silk textiles were discovered in the parcels of generally well-situated people: town councillors, aldermen and rich merchants. It confirms the thesis that silk textiles, especially the most decorative ones, are a perfect indication of the social standing of their owners.

The confrontation of archaeological evidence with written sources undoubtedly brings interesting results. A great correspondence of these sources as far as textile evidence is concerned can be observed: types of textiles listed in the sumptuary laws were successfully identified in the excavated evidence. However, it should be stated that in the case of other categories of artefacts related to clothing, like decorative items or jewellery, historical accounts have not been reflected in archaeological sources. ${ }^{26}$

\footnotetext{
${ }^{22}$ Czacharowski, Kartoteka...

${ }^{23}$ Czacharowski, Kartoteka...

${ }^{24}$ Maik 2004, 511, 512, Fig. 8.

${ }^{25}$ Czacharowski, Kartoteka ...

${ }^{26}$ Rybarczyk 2016, 234-235.
} 


\section{Bibliography}

Acten der Ständetage Preussens unter der Herrschaft des Deutschen Ordens, Band 2, Toeppen M. (ed.), Leipzig 1880.

Campbell M. 2009. Medieval Jewellery in Europe 1100-1500. London.

Czaja R. 1992. Socjotopografia miasta Elblaga w średniowieczu. Toruń.

Czacharowski A. (ed.), (n.d.). Kartoteka działek mieszczańskich Starego Miasta w Elblagu. Typescript (with unnumbered pages) in the possession of the Museum of Archaeology and History in Elbląg.

Drążkowska A. 2012. Ozdoby i nakrycia głowy na ziemiach polskich od X do końca XVIII wieku. Toruń.

Grupa M. 2009. Tkaniny z krypty pótnocnej w Kwidzynie / Textiles from the Northern Crypt in Kwidzyn. In: M. Grupa, T. Kozłowski (eds.), Katedra w Kwidzynie - tajemnica krypt / Kwidzyn Cathedral-the Mystery of the Crypts. Kwidzyn, 149-174.

King D., King M. 1988. Silk Weaves of Lucca in 1376. In: I. Estham, M. Nockert (eds.), Opera Textilia Variorum Temporum. To Honour Agnes Geijer on Her Ninetieth Birthday $26^{\text {th }}$ October 1988. Stockholm, 67-76.

Maik J. 1997. Sukiennictwo elbląskie w średniowieczu. Acta Archaeologica Lodziensia 41. Łódź.

Maik J. 2004. Średniowieczne jedwabie z wykopalisk w Elblagu. In: R. Czaja, G. Nawrolska, M. Rębkowski, J. Tandecki (eds.), Archaeologia et historia urbana. Elbląg, 509-516.

Mancini A., Dorini U., Lazzareschi E. 1927. Lo Statuto Della Corte dei Mercanti in Lucca del MCCCLXXVI. Florence.

Rybarczyk A. 2016. Odzież i akcesoria stroju w średniowiecznym Elblagu. Unpublished PhD thesis. Institute of Archaeology and Ethnology, Polish Academy of Sciences.

\section{Internet sources}

http://www.nationalgallery.org.uk/paintings/jan-van-eyck-the-arnolfini-portrait (accessed 3.04.2018).

\section{Streszczenie}

\section{Tekstylia i status społeczny. Przypadek późnośredniowiecznego Elbląga}

W średniowieczu wysokiej jakości tekstylia były bez wątpienia jednym z najbardziej luksusowych wyrobów. Z tego względu drogie tkaniny, zwłaszcza jedwabne, są uznawane za wyznaczniki wysokiej pozycji społecznej. Połączenie wiedzy pozyskanej ze źródeł archeologicznych i historycznych daje możliwość przyjrzenia się zagadnieniu wykorzystywania kosztownych tkanin przez mieszkańców późnośredniowiecznego hanzeatyckiego miasta. Celem artykułu jest podjęcie takiej próby na podstawie źródeł pisanych oraz archeologicznych. W trakcie badań wykopaliskowych na terenie Elbląga pozyskano bardzo interesującą kolekcję tekstyliów. Ustalenie ich właścicieli było możliwe dzięki pochodzeniu znalezisk z dobrze rozpoznanych historycznie działek mieszczańskich. Konfrontacja materiałów archeologicznych z przekazami pisanymi przyniosła interesujące rezultaty, np. z powodzeniem zidentyfikowano $\mathrm{w}$ analizowanym zbiorze rodzaje tkanin wymieniane w przepisach przeciwzbytkowych. 
